\title{
In search of the missing Robert Mangaliso Sobukwe
}

[ B O O K R E VIEW]

Benjamin Pogrund (2015 - new edition)

How can man die better: The life of Robert

Sobukwe. Johannesburg \& Cape Town:

Jonathan Ball Publishers (1990).

ISBN 978-1-86842-681-2 pbk. Pages 427

There is a certain pathos at the heart of the story of neglect that RobertSobukwe has suffered in South Africa's political history, and especially so since the advent of democracy in 1994. It seems that he is remembered, in a few street names and such, so that he can quickly be forgotten! And yet, Sobukwe and his ideas, refuse to be removed from the fabric of everyday consciousness, as though their ghostly presence haunts our political conscience. In the last few years there have been many short articles that either invoke the name and significance of Sobukwe, or are directly trying to make a case for his continuing relevance and importance in South Africa's contemporary political scene (see amongst others, Ndletyana, 2013; Gqola, 2014; Lebelo, 2015; Pogrund, 2015; Maserumule, 2016; Mkhwanazi, 2016).

What, one might ask, is so unsettling or threatening about Robert Sobukwe and his ideas that he seems to be denied a proper place as one of the "struggle heroes" (to quote Ndletyana, 2013) of South Africa? The reasons for the repression of Sobukwe in the political history of South Africa, both in the political and psychoanalytic sense of the term, need to be explored at length if we are to understand the persistence of his exclusion for the political mainstream. However, in the meantime, it is worth briefly suggesting some reasons for this "political

\section{Grahame Hayes}

Durban

grahame.hayes@gmail.com 
anomaly". Clearly one of the main reasons has to do with the political dominance of the ANC, and their concern, to put it mildly, of writing the history of South Africa's struggle for freedom against racial oppression as all their own doing. This is a triumphalist history that does not easily tolerate contending views. As Pogrund (2015: 410-411) himself notes "Meanwhile, South Africa has not been kind to Robert Sobukwe. The magnitude of his deeds and beliefs is largely ignored. The African National Congress in government has done much to airbrush him out of the freedom struggle. He is seldom referred to." Another more complex consideration is the struggle over political ideas, and hence the ANC's hegemonic Charterist position versus the Africanist position of Sobukwe (and other early PAC leaders). It would of course be far too simplistic to see the ANC - PAC split as only about differing positions regarding what it means politically to be an African. A contemporary resonance of the complexity of what political identity means these days in South Africa is to be found in many of the spokespeople of the \#Fallist movements, who, while some claim to (still) be ANC members, also call themselves Africanist, and espouse a black consciousness. Recent graffiti on university campuses has championed Sobukwe, Biko, and Fanon mainly, and not ANC "struggle heroes" (cf Mkhwanazi, 2016). A final reason for Sobukwe's political exclusion might have something do with the (lack of) moral fibre of the ruling ANC government. Reading Pogrund's (2015 - new edition) biography it is obvious that Sobukwe was a man of immense moral integrity. So a "return" to Sobukwe would take us back to a time of ethical leadership, and where most political leaders seemed incorruptible. So it seems not all nostalgia is reactionary!

While it is understandable, even if not acceptable, that Robert Sobukwe has been "forgotten" as a political figure in South Africa's struggle for freedom, what is more puzzling is why his supporters, then and now, and intellectuals with an interest in the political history of South Africa have not kept the name, ideas, and work of Sobukwe alive. In preparation for this book review I thought I would read as much of Sobukwe's work that I could get hold of. In my misplaced optimism I thought I would find a book of his speeches and writings - no such luck! Sobukwe's work (mostly speeches) is scattered all over the place, and two speeches regularly feature in the few resources that do contain material on, and of, Sobukwe: the first is his address on behalf of the graduating class at Fort Hare College, delivered at the "Completers' social" on 21 October 1949; and the second is his inaugural address (4 April 1959) to the founding congress of the Pan Africanist Congress, 4-6 April 1959 (see: https://ilizwe.files.wordpress.com/2012/10/panafricanist-congress-basic-documents-2000-constitution.pdf). These two speeches are important documents as they set out the Africanist position as distinct from the prevailing views of the ANC at the time. Obviously the Karis and Carter (1987) documentary history of African politics, volumes three and four, contains material on the PAC, and thus some speeches by Sobukwe. The Internet brings some relief, but not much. Wikipedia has a very brief (three page) entry on Sobukwe. Other online resources are the South African 
History Online website (http://www.sahistory.org.za/people/robert-mangaliso-sobukwe), and the Historical Papers Research Archive at the University of the Witwatersrand (see: http://www.historicalpapers.wits.ac.za/?inventory/U/collections\&c=A2618/R/). The latter resource has all of Benjamin Pogrund's papers dealing with Sobukwe that he donated in September 1997. These contain the hundreds of letters between "Bob" Sobukwe and "Benjie" Pogrund during Sobukwe's incarceration, and especially his six years on Robben Island (1963-1969).

However, it seems that things might be looking up with regard to a new interest, and thus recovery, of the ideas of Sobukwe. In his "Epilogue" (pp 385-414) Pogrund tells us that, "Significantly, a resurgence of interest in Sobukwe was developing in 2015. It is described by Dr Derek Hook, a South African-born social psychologist at Duquesne University, in Pittsburgh, who is writing a biography of Sobukwe. Hook notes that another major study is being written in South Africa, with other assessments under way in universities and political circles." ( $p p$ 411-412). There follows a long ( $p p$ 411-414) commentary from Derek Hood about contemporary South African politics and why he thinks the moment is right for a resurgence of interest in Sobukwe. Unfortunately, besides Hook's intended / forthcoming biography, we are not told by Pogrund what these other works and assessments are, or when they might appear. Thankfully, while we wait for these other works to appear, we have Benjamin Pogrund's updated new edition (2015) of How can man die better: The life of Robert Sobukwe, that was first published in 1990.

This remarkable biography has been the standard text on the life and ideas of Sobukwe, and through its many reprintings over the years has kept Sobukwe in the public eye. While Pogrund's text is mainly a story about Sobukwe's life, the development of his political ideas, and his role as a PAC leader, it is also a story of two friends. As Tom Lodge (1991) pointed out, in a review of the first edition of Pogrund's biography, it "tells two stories. The first is a fairly straightforward 'life and times' of a politician: childhood, upbringing, education, professional career, intellectual formation, and organisational activities - a narrative generally confined to the public personality and not the private man. The second story concerns the development of a friendship ... " And yet there are many layers (and other stories) within these two stories: indeed, a story of the life of Sobukwe; a story of the development of the ideas that resulted in the Africanist breakaway from the ANC, and the founding of the PAC in April 1959; a political history of the struggle against apartheid during the 1960s and 1970s; the story of the development of a friendship between a white liberal journalist and a black radical Africanist intellectual; and a part autobiography of Benjamin Pogrund.

How can man die better is a big book (at 427 pages), and so it should be to properly tell the story of Robert Sobukwe's life in the detail that it deserves. Pogrund gives us a lot 
of detail starting with Sobukwe's upbringing, his schooling at Healdtown High, his years as a student at Fort Hare College, his teaching career in Standerton, his lectureship in African languages at the University of the Witwatersrand, the formation of the PAC and his presidency, through to the ghastly years of his imprisonment and especially the six years on Robben Island, to finally his release from prison and banishment to Kimberly where he qualified as a lawyer, and in the end his early death form cancer at the age of 53 on 27 February 1978. The details of Sobukwe's life and struggles are not from some distant observer, but from a friend, a participant in Sobukwe's life and from someone deeply concerned about the welfare of his friend and fellow-traveller. This care, and love, for his friend (and Sobukwe's family - Veronica, his wife, and their children) is evident in the chapters (from chapter 11) discussing Sobukwe's time on Robben Island. Pogrund went to great lengths to make Sobukwe's stay on Robben Island as "liveable" as possible, from arranging food and fruit deliveries from Stuttafords in Cape Town to Robben Island, to arranging reading and study material, to writing letters to the authorities for Sobukwe's release and requesting extended visits from his wife and family. Sobukwe's conditions of detention on Robben Island were very different from all the other prisoners. While he lived on his own and was not allowed contact with the other prisoners, he lived in a small house that was reasonably well furnished, he never wore prison issue clothes and could arrange his own clothing to be sent to the Island, he was granted study privileges and was allowed to receive books, magazines and newspapers.

Given the usual brutality of the apartheid regime he was oddly treated with respect and a modicum of dignity. And yet the regime clearly feared the influence he would have if he was released. As Karis and Gerhart (1987: 149) observe in their political profile on Sobukwe: "Eloquent and impassioned on the public platform, and biting in his attacks on all 'enemies of the people' - white and nonwhite, Sobukwe had the makings of a powerful mass leader." Clearly this mass appeal of Sobukwe was what threatened the apartheid authorities in their continued detention of him year after year on Robben Island. After Sharpeville the detention (without trial) periods had been extended from 12 days to 180 days. This was not sufficiently long enough time as far as Sobukwe was concerned and he was detained under a clause written into the General Law Amendment Act in 1963 - the "Sobukwe Clause". Pogrund gives us the cruel detail of this law in the following account: "The law was put into effect for just over a year, until 30 June 1964, but could then be extended for periods of twelve months by a resolution of Parliament - which made renewal a formality. As will later be seen, that indeed is what was done year after year until the law finally was allowed to expire after six years. It was known as the 'Sobukwe Clause', and he was the only person against whom it was used.' (pp 184-185).

Pogrund met Sobukwe in 1957 and stayed a close friend of his until the end. One could dwell on this 21 year period of Sobukwe's life in a mournful way: his arrest following the 
Sharpeville massacre of 1960; his imprisonment, and the six years on Robben Island; his banishment to Kimberley; and then his untimely death. As sad as the events of Sobukwe's are, Pogrund's book is not a mournful account, but in many senses a celebration of an exceptional man who had a lot to offer South Africa, and Africa, had he been allowed to. The first half of the book is full of quotes from Sobukwe, and from Sobukwe's comrades and associates, which show a man full of humanity for his fellow human beings, nonracial to the core of his being, committed to African emancipation both in the sense of ordinary African people and the continent of Africa from exploitation, oppression and colonialism, and a towering intellectual. As Sobukwe said himself: "I wish to make it clear again that we are anti-nobody. We are pro-Africa. We breathe, we dream, we live Africa; because Africa and humanity are inseparable." (see Pogrund, p 37). Whatever one wants to make of Sobukwe's views about African Nationalism, the importance of acknowledging our continental (Africa or Afrika) connectedness, nonracialism versus multi-racialism, there can be no denying that we aren't too far down the road in terms of realising a society that is non-racial and making serious inroads into the obscene, and increasing, levels of inequality. Pogrund's biography of Sobukwe is not uncritical, but he refrains from judging Sobukwe, and rather presents him to us in an open way so that we can make up our own minds. And to repeat Pogrund's comment that South Africa has not been kind to Sobukwe, this is the least that he deserves.

I want to end this review with Pogrund's final paragraph ( $p$ 414):

"With all the failure and dashing of dreams in South Africa after twenty-one years [2015] of freedom, optimism remains. There is no shortage of doomsayers, and they can point to much to support their view. Yet the spirit of hope is found wherever you look. It was embedded among blacks in the many years of enduring white domination and apartheid. It now runs deep in the belief that South Africans have suffered and have struggled and they can and will overcome. It is exactly what Robert Mangaliso Sobukwe believed until he died."

\section{References}

Gqola, P D (2014) Africa is still waiting for the dawn. M\&G Online, 30 May 2014. http://mg.co.za/article/2014-05-29-africa-is-still-waiting-for-the-dawn

Karis, T \& Carter, G M (eds) (1987) From protest to challenge: A documentary history of African politics in South Africa, 1882-1964. Volume 3 - Challenge and violence, 1953-1964. Stanford, Ca: Stanford University / Hoover Institution Press (1977). 
Karis, T \& Carter, G M (eds) (1987) From protest to challenge: A documentary history of African politics in South Africa, 1882-1964. Volume 4 - Political profiles, 1882-1964 - Gerhart, G M \& Karis, T. Stanford, Ca: Stanford University / Hoover Institution Press (1977).

Lebelo, S (2015) Imprisoned by the Freedom Charter. Mail \& Guardian, 3-9 July 2015.

Lodge, T (1991) A liberal of another colour. Transformation, 16, 76-88.

Maserumule, M H (2016) Sobukwe's pan-Africanist dream: An illusive idea that refuse to die. The Conversation, 16 February 2016. http://theconversation.com/sobukwes-panafricanist-dream-an-elusive-idea-that-refuses-to-die-52601

Mkhwanazi, K (2016) Paint speaks to power. Mail \& Guardian, 18-23 March 2016.

Ndletyana, M (2013) Lest we forget our struggle heroes. Sunday Independent, 24 March 2013. http://www.iol.co.za/sundayindependent/lest-we-forget-our-struggleheroes-1490711

Pogrund, B (2015) New life for old ideas. Daily Dispatch, 11 July 2015. 